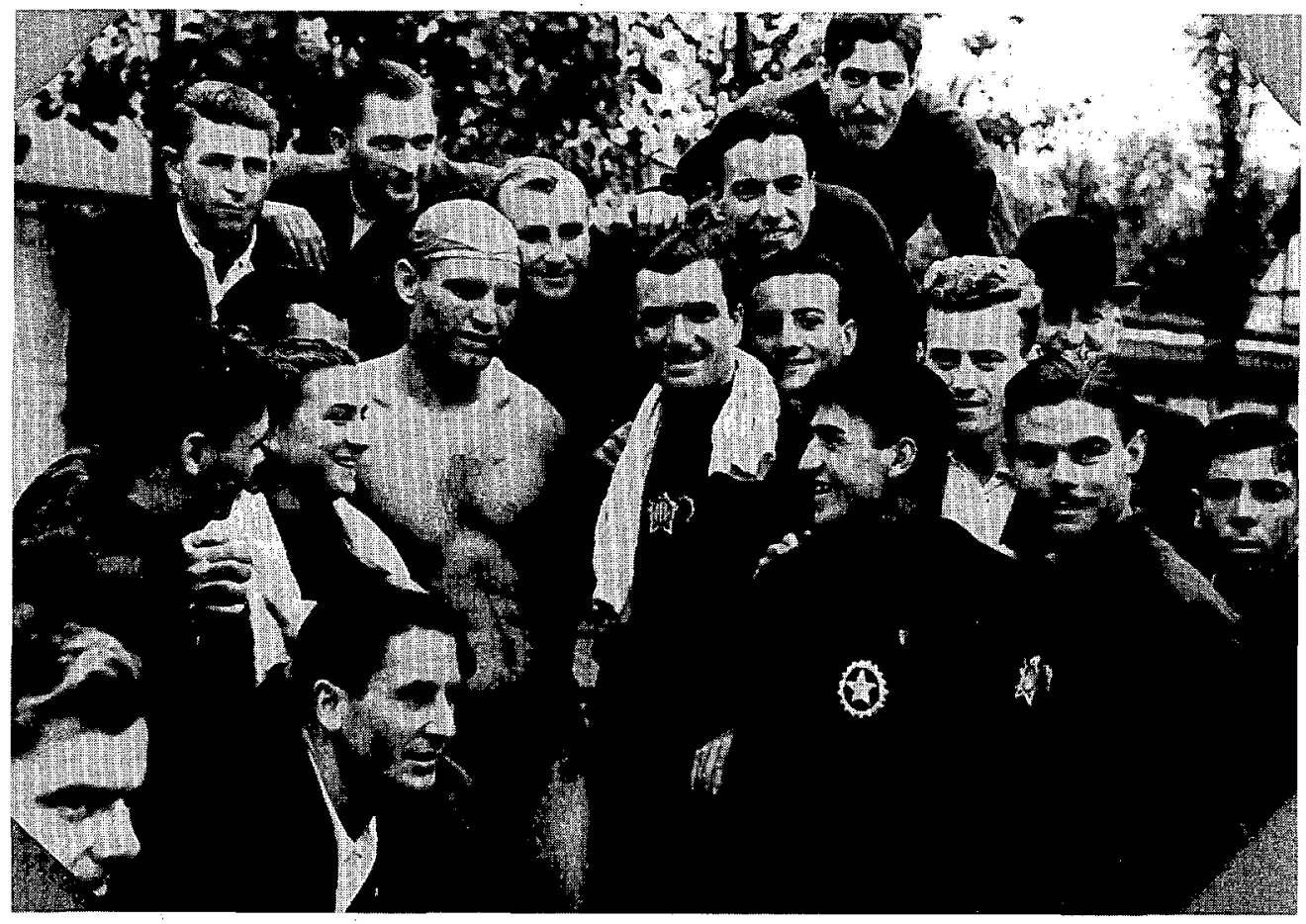

De Russische zwemmet S. Boitsjenko op de Derde Arbeidersolympiade te Antwerpen 


\title{
De Arbeidersolympiade van 1937 in Antwerpen, in het licht van de ontwikkeling van de internationale arbeiderssportbeweging tijdens het Interbellum
}

\author{
Geert Van Goethem, wetenschappelijk \\ medewerker AMSAB-CLM
}

\section{Arbeiderssport, functie en doel}

Sport en socialisme zijn beide fenomenen waarvan het ontstaan en de ontwikkeling zich situeren binnen de nieuwe, industriële samenleving, die vanaf het midden van de vorige eeuw het uitzicht van de maatschappij fundamenteel heeft veranderd.

Beide fenomenen hebben ogenschijnlijk weinig met elkaar te maken. Sport richtte zich aanvankelijk tot een bovenklasse van 'gentlemen', maar naarmate de arbeidersbeweging haar eerste successen boekte in de strijd voor de vermindering van de arbeidsduur, werden zowel de sportbeoefening als de sportconsumptie bijzonder populair bij de arbeidersklasse, zodanig dat de sport zowel een rekruterings- als propagandamiddel werd.

Het succes van de burgerlijke sportbeoefening werd door socialisten trouwens als een gevaar gezien, de aandacht van de arbeiders werd afgeleid van hun proletarische opdracht en de burgersport zelf met zijn prestatie- en competitiedruk werd beschouwd als een uitwas van de kapitalistische maatschappij. De Olympische spelen, die op het einde van de eeuw opnieuw werden ingericht in een klimaat van toenemend nationaal chauvinisme waren voor de socialistische beweging de voorafbeelding van de oorlogen tussen de naties.

De arbeiderssportbewreging ging zich daarom ontwikkelen als tegenbeweging, met het doel de arbeiders weg te trekken van de verderfelijke invloed van de burgersport; de arbeidersklasse zich evenwichtig en klassebewust te laten ontwikkelen mét waarden als samenwerking, internationalisme en pacifisme. De arbeiderssport, die aanvankelijk vooral bestond uit turngroepen, werd een deel van de socialistische subcultuur, naast muziek, toneel, fotografie, jeugdbeweging...

De ontwikkeling van deze subcultuur paste in de strategie van de reformistische socialistische bewegingen, die in 1889 de Tweede Interna- 


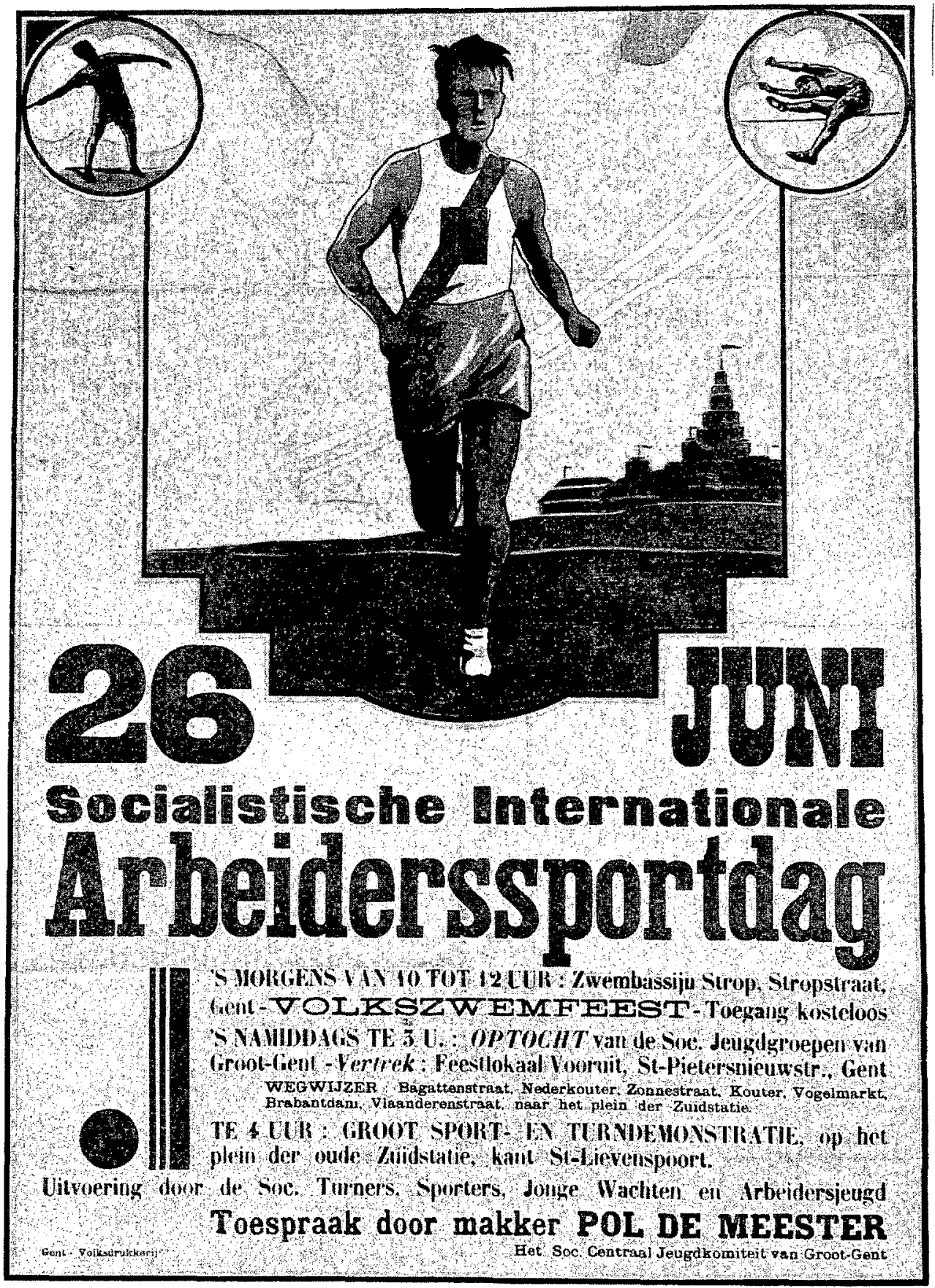

1. D F E

De lichamelijke opvoeding, doot sport of turnen, was essentieel in de vorming van een proletarische jeugd 
tionale hadden opgericht. Op het congres van de Socialistische Internationale van 1900 in Parijs werd in een motie een tekst van Kautsky aangenomen, die zowat als het credo kan gelden van de toenmalige sociaal-democratie: "Dans un Etat démocratique moderne, la conquête du pouvoir par le prolétariat ne peut être le résultat d'un coup de main, mais bien d'un long et pénible travail d'organisation physique et morale de la classe ouvrière et de la conquête graduelle des municipalités et des assemblées législatives."

De morele'en fysieke opvoeding van de arbeidersklasse maakte dus voor Kautsky integraal deel uit van de veroveringsstrategie van het democratische socialisme. Het is duidelijk dat in deze optiek de stiçhting van eigen, klassegerichte organisaties op al deze diverse actieterreinen een eerste doelstelling was. De internationale samenwerking tussen deze organisaties was een logische stap, die dan ook niet lang op zich zou laten wachten.

\section{De internationale arbeiderssportbeweging}

In 1912 werd in Stockholm de vijfde Olympiade georganiseerd. De enorme populariteit van dit wereldsportevenement en de nationalistische oprispingen die ermee gepaard gingen leidden tot een reactie bij de Socialistische Internationale en bij de arbeiderssportfederaties van Frankriik en België. Engelse, Franse en Oostenrijkse arbeiderssportgroepen werden uitgenodigd door de Belgische arbeiderssportfederatie voor een internationaal congres dat plaats had op 10 mei 1913 in Gent. Dit congres besliste tot de oprichting van de 'Association Socialiste Internationale d'Education physique' (ASIEP), waarbij op te merken valt dat de term 'éducation physique' hier gebruikt werd in zijn globale betekenis. De lichamelijke opvoeding, door sport of turnen, was essentieel in de vor- ming van een proletarische jeugd "capable d'être la digne continuatrice de ceux qui semèrent la bonne graine, les pionniers de la première heure..." zoals de Belg Gaston Bridoux, de eerste voorzitter van de arbeiderssportinternationale het uitdrukte.

Grote afwezigen bij de stichting van deze nieuwe internationale waren de Duitse organisaties, want vooral in dit land was de arbeiderssportbeweging al snel bijzonder succesvol. De in 1893 gestichte Arbeiter-turnerbund (ATB) telde in 1912 al 183.000 leden en de Arbeiterradfahrerbund had in 1910 ongeveer 100.000 leden. Deze Duitse organisaties stonden aanvankelijk vrij weigerachtig tegenover een internationale van de arbeiderssport en waren beducht voor een té sterke indentificatie met de socialistische beweging. Pas in de lente van 1914 zou de Arbeiter-turnerbund aansluiten en meteen het tweede congres organiseren.

Het uitbreken van de Eerste Wereldoorlog zou dit echter beletten. Net zoals de andere internationale socialistische organisaties viel ook de arbeiderssportbeweging uit elkaar. De oorlog zou ook hier diepe wonden slaan en een reconstructie van de ASIEP was niet evident. De Belgische voorzitter Bridoux wou de organisatie opnieuw oprichten maar zonder de Duitse en Oostenrijkse federaties, hetgeen vooral voor de Fransen niet aanvaardbaar was. Bridoux volgde hiermee de houding van de meerderheid binnen de Belgische socialistische beweging, die ook op andere terreinen van internationale actie Duitse deelname wilde beletten.

De poging van Bridoux om de ASIEP herop te richten tijdens de internationale bijeenkomst in het Belgische Seraing op 16 augustus 1919 mislukte daarom. Pas in september $1920 \mathrm{kon}$ in Lucerne worden overgegaan tot de oprichting van een nieuwe arbeiderssportinternationale. 


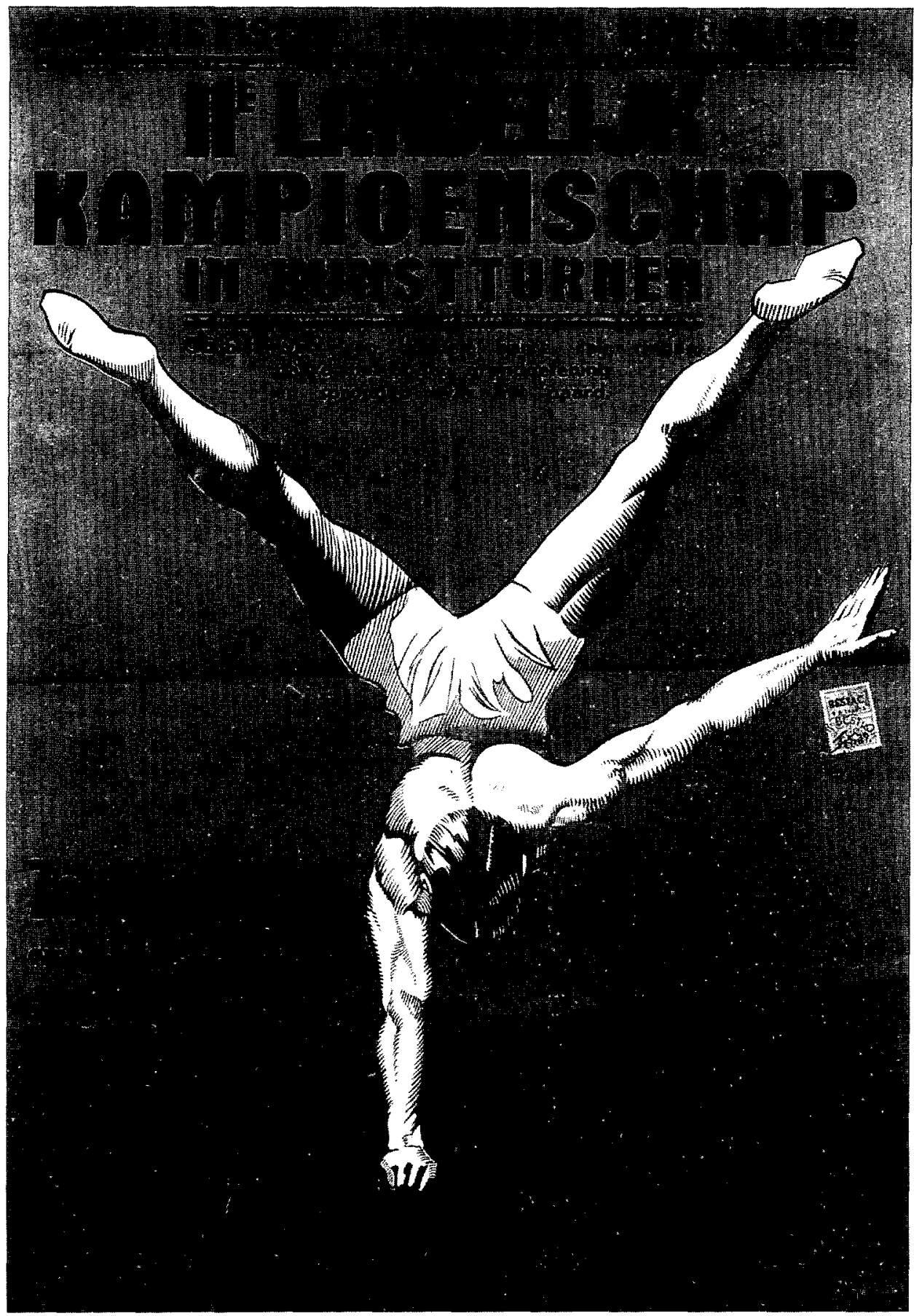

Op haar hoogtepunt bereikte de arbeiderssportbeweging slechts $25 \%$ van de sportbeoefenende arbeiders 
De nieuwe internationale, de 'Union Internationale d'Education Physique et Sportive du Travail', die beter bekend werd onder de roepnaam 'Internationale Sportive de Lucerne' (ISL), had de ambitie om alle arbeiderssporters, wat ook de politieke tendens was waartoe ze zich bekenden, te verenigen. Deze duidelijke poging om de communistisch geörienteerde organisaties binnen de beweging te houden werd echter nagenoeg onmiddellijk gecounterd door de oprichting van de 'Internationale Rouge Sportive' (IRS) in 1921 in Moskou. De houding van de IRS tegenover de internationale van Lucerne werd bepalend beïnvloed door de strategie van de Komintern; beide internationales zouden elkaar tussen 1921 en 1934 dan ook heftig bekampen.

Zowel op het vlak van de aangesloten organisaties, de leidende figuren als de ideologie was de ISL de voortzetting van het vooroorlogse initiatief. De ISL bestond uit de nationale arbeiderssportfederaties van Frankrijk, Duitsland, Oostenrijk, Groot-Brittannië, België, Finland, Zwitserland en Tsjecho-Slowakije. De zetel bleef in Brussel en de Belgen Gaston Bridoux en Jules Devlieger namen het voorzitterschap waar. Ideologisch bleef de klemtoon liggen op samenwerking en tegen de competitie. Het internationalisme kreeg na de gruwelen van de oorlog extra aandacht en 'vrede door sport' werd het leitmotiv van de internationale arbeiderssport. De Duitser Franz Wildung drukte het in 1922 als volgt uit:

"In our sporting events we must face each other eye to eye and get to know that none of the others is an enemy, buth rather that all men are brothers... We have the most powerful interest that the great world-wide lies spread by capitalism finally be destroyed, that the people leam that they are thousend times more unified than divided".
Indien de ambitie om de internationale vrede te bereiken door de arbeiders van de wereld samen te brengen op de sportvelden moest gerealiseerd worden, dan moesten de sportmanifestaties efficiënt georganiseerd worden, in groten getale en op dusdanige manier dat zowel het politieke bewustzijn als de sportieve ontwikkeling werden gestimuleerd. De arbeiderssportbeweging ontwikkelde een dynamische internationale actie; tussen 1926 en 1934 werden niet minder dan 966 sportevenementen georganiseerd onder auspiciën van de ISL. De arbeiderssportbeweging was daarmee een belangrijke actor op de internationale sportscène die in volle ontwikkeling was.

De strijd voor de vermindering van de arbeidsduur en de verovering van de achturige werkdag kort na het einde van de oorlog luidde een bijzonder expansieve periode in voor alle vormen van vrijetijdsbesteding en de sport in het bijzonder. Sporten zoals voetbal en wielrennen werden enorm populair. In Frankrijk groeide het aantal voetbalclubs van 659 in 1919 naar 3983 in 1923 en de Duitse voetbalbond zag zijn ledental stijgen van 150.000 in 1919 tot meer dan één miljoen in 1920.

Maar deze toenemende populariteit van de sport had ook haar schaduwkanten voor de arbeiderssportbeweging. Op haar hoogtepunt bereikte de arbeiderssportbeweging slechts ongeveer $25 \%$ van de sportbeoefendende arbeiders. Het aantal arbeiders dat deel uitmaakte van sportverenigingen buiten het georganiseerde socialisme overtrof dan ook in belangrijke mate de aanhang van de verenigingen voor arbeiderssport. Immers, de burgerlijke sportorganisaties, met hun op prestatie gerichte sportethiek en het streven naar sensatie dat daarmee samenging, waren enorm populair. Dit had in zoverre een invloed op de arbeiderssportbonden, 


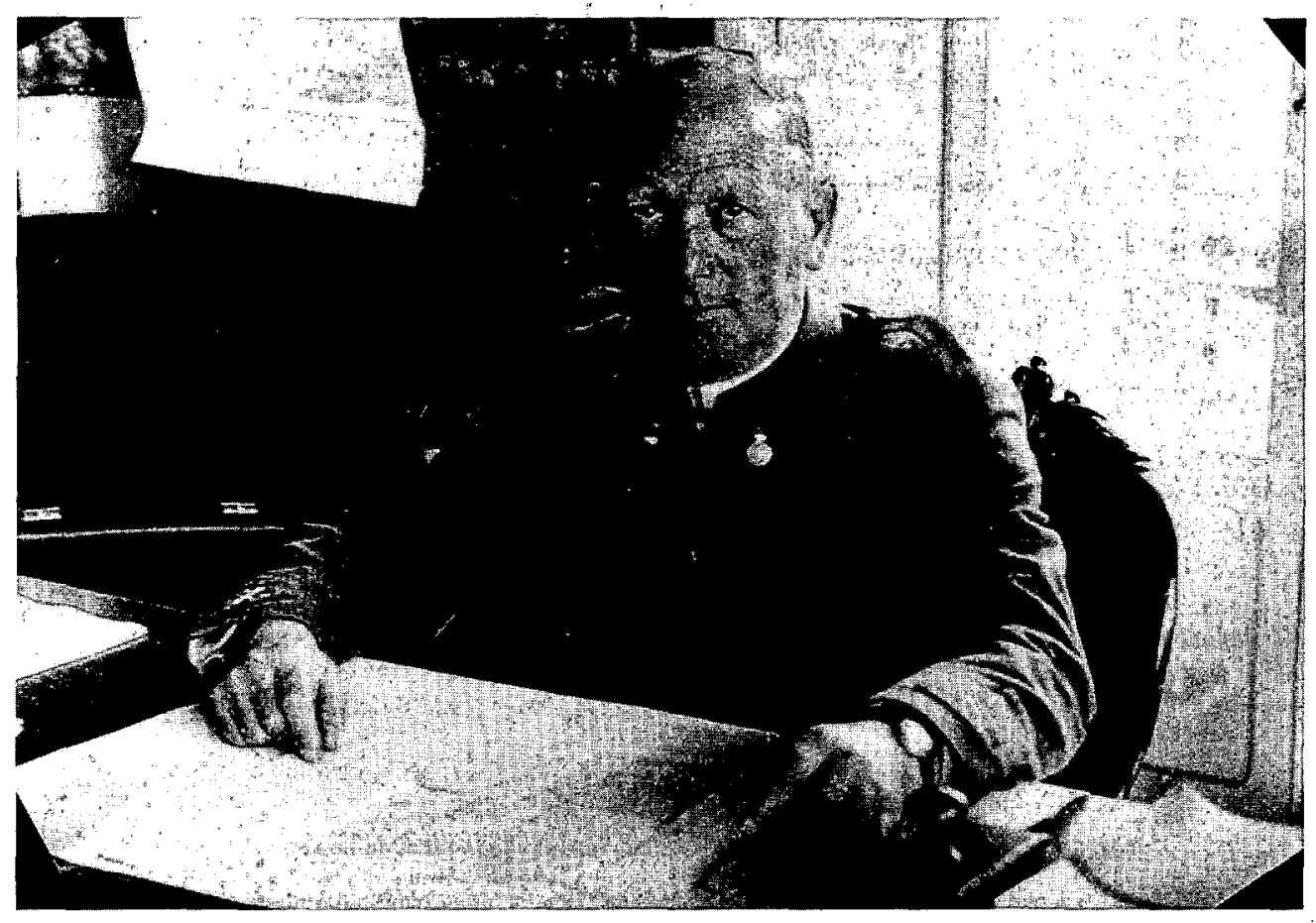

Julius Deutsch, Oostenrijks voorzitter van de Intemationale Sportive Ouvrière Socialiste (ISOS) 
dat ook zij elementen van competitie en prestatie moesten toelaten. Politieke bewustwording, vredesstreven en samenwerking bleven echter de kernbegrippen van de arbeiderssportbeweging.

\section{De Arbeidersolympiades van}

\section{Frankfurt en Wenen}

De arbeidersolympiades waren dan ook zowel sportieve als politieke evenementen. Het idee van de arbeidersolympiades kwam van de Tsjechische federatie, die zelf eigen olympiades organiseerde. Op het ISL-congres van 1922 in Leipzig werd beslist om in 1925 een arbeidersolympiade te organiseren in Frankfurt am Main. Tussen 24 en 28 juli 1925 verzamelden zich 45.000 deelnemers uit 19 landen. 150.000 Mensen zouden het evenement als toeschouwer hebben meegemaakt. Deze cijfers alleen al maken duidelijk dat de arbeiderssport zich zowel in zijn deelnemers als in zijn publiek tot de massa richtte en dat er ook massaal werd aan deelgenomen.

Het politieke karakter van de manifestatie werd onderstreept tijdens de openings- en overwinningsceremonie, zonder nationale vlaggen of hymnes, maar wel met de rode vlag en de Internationale. Het eigen karakter van de arbeiderssport kwam vooral tot uiting in de massademonstraties onder het thema 'Volkerverständigung und -versöhnung', maar daarnaast waren er ook competities in zwemmen, wielrennen, atletiek, voetbal, waterpolo, handbal, boksen en worstelen. Gastland Duitsland domineerde de meeste van deze competities, behalve de atletiek waar de Finnen de meeste overwinningen behaalden.

Het gebeuren kreeg uitvoerige aandacht, vooral in de socialistische pers en het werd zelfs gefilmd, zodat honderdduizenden in de cine- ma's van de Volkshuizen getuige waren van deze eerste arbeidersolympiade, wat enorm moet bijgedragen hebben tot de populariteit en het prestige van de arbeiderssportbeweging.

Ondanks de financiële kater die de Duitse organisatie eraan overhield werd beslist om de arbeidersolympiades voort te organiseren aan een ritme van én per zes jaar. De arbeiderssportbeweging kwam nu tot volle maturiteit. Vooral in Centraal en Oost-Europa genoot de beweging een enorme aanhang. De Duitse, Oostenrijkse en Tsjechische bonden domineerden qua ledental. Het feit dat zowel de zetel als het voorzitterschap in handen was van de relatief onbeduidende Belgische federatie was dan ook niet langer houdbaar. Op het ISL-congres van 1927 in Helsinki werden de structurele veranderingen doorgevoerd die zich opdrongen. De zetel van de internationale verhuisde van Brussel naar Praag, terwijl het voorzitterschap in handen kwam van een DuitsOostenrijks duo: Gellert uit Leipzig en Julius Deutsch uit Wenen. De internationale kreeg ook een nieuwe naam: 'Internationale Sportive Ouvrière Socialiste' (ISOS). De arbeiderssportbeweging werd nu een volwaardige tak van het internationale socialisme, naast de Socialistische Arbeidersinternationale, het Internationaal Vakverbond en de Socialistische Jeugdinternationale. De werking werd geprofessionaliseerd, met onder andere een technische commissie, een eigen persdienst en een commissie ter bevordering van de vrouwensport. De ISOS bereikte op haar hoogtepunt rond 1930 ruim 2 miljoen leden, waarvan de helft geleverd werd door de Duitse Arbeiter-Turn und Sportbund.

De tweede arbeidersolympiade, die van 19 tot 26 juli te Wenen werd georganiseerd zou hét hoogtepunt worden van de sociaal-democra- 


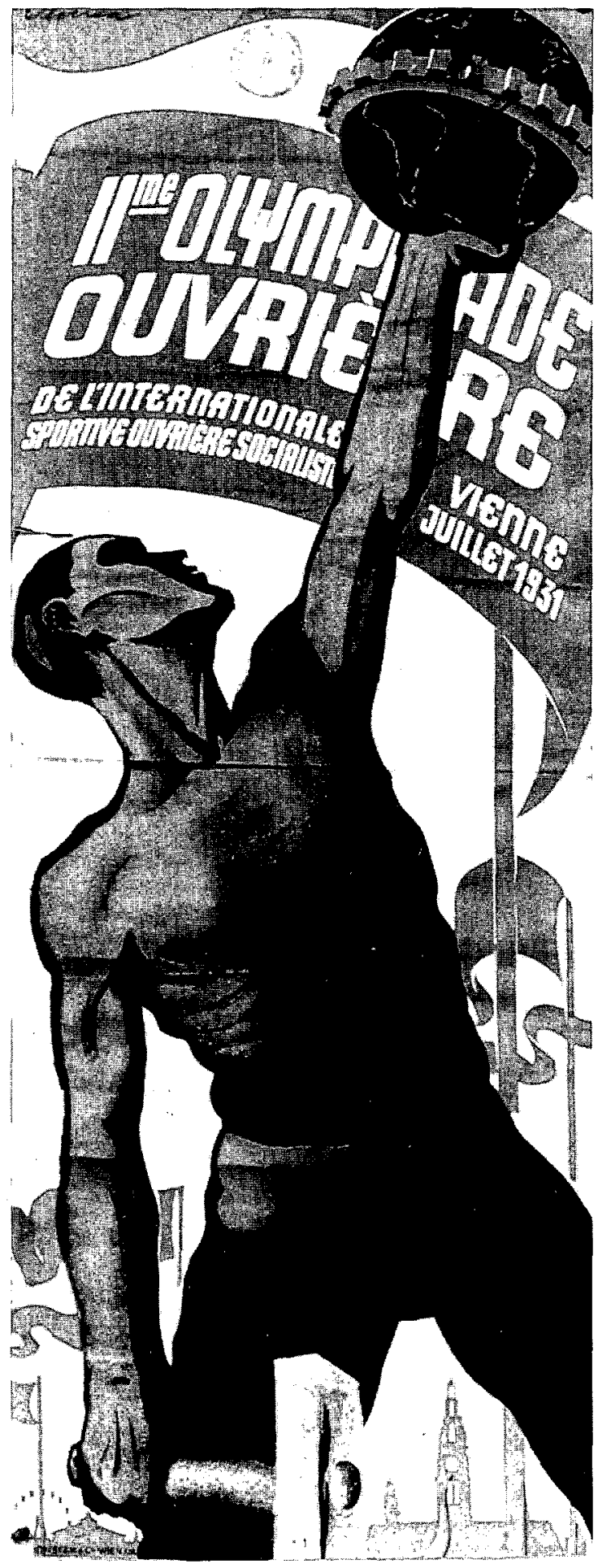

De Tweede

Arbeidersolympiade te Wenen werd hét hoogtepunt van de sociaal-democratische arbeiderssportbeweging 
tische arbeiderssportbeweging met bijna 80.000 deelnemers uit 26 landen en 250.000 toeschouwers. Aan de Olympische spelen van Los Angeles, het jaar daarop, namen 37 landen deel, met 1400 atleten. Uit deze cijfers blijken zowel de internationale impact van de arbeiderssportbeweging als haar eigen karakter als massasportevenement.

Zoals in Frankfurt lag de klemtoon van de Weense olympiade duidelijk niet op de competitie. Er was een groot kindersportfestival, een feestelijke parade, vuurwerk, massaturnen en een gecombineerde loop- en zwemtocht door Wenen. Wenen was de olympiade van de hoop, ondanks de donkere wolken aan de horizon.

Op het ISOS-congres van 1932 was de dreiging van het oprukkende fascisme al duidelijk voelbaar en de arbeiderssportbeweging sloot zich volledig aan bij de actie van het internationale socialisme tegen het rechtse extremisme. Het verbieden door de nazi's van de Duitse arbeiderssportorganisaties in 1933 en het verlies van de Oostenrijkse bonden in 1934 betekende dat de ISOS in één klap meer dan de helft van de leden verloor, samen met een belangrijk deel van de technische middelen en kennis.

Onder deze omstandigheden won de mening veld dat de beweging zich niet langer de luxe van politieke verdeeldheid tussen socialisten en communisten kon permitteren. Het zevende ISOS-congres te Karlsbad nam een eenheidsresolutie aan, ingediend door Julius Deutsch, die stelde dat "Was uns politisch trennt, spielt in dem Augenblick, in dem die ganze Arbeiterklasse gegen den drohende Faschismus kämpfen muss, eine untergeordnete Rolle". Deze resolutie sloot aan bij de nieuwe eenheidsfrontstrategie die de Komintern vanaf 1934 verdedigde. De ISOS en de IRS kwamen nauwer tot elkaar en op 6 september 1935 tekenden afgevaardigden van beide internationales een oproep aan de atleten van de ganse wereld om de olympiade van Berlijn te boycotten. De internationale arbeiderssportbeweging was daarmee zowat het enige terrein waarop een structurele samenwerking tussen socialistische en communistische internationales tot stand kwam.

Een ander besluit van het congres van Karlsbad was dat er, ondanks de verzwakte positie van de arbeiderssportbeweging, toch een nieuwe olympiade zou worden georganiseerd. De organisatie werd toevertrouwd aan de Belgische federatie die Antwerpen, de stad van burgemeester Camille Huysmans, als locatie naar voor schoof.

\section{De arbeiderssportbeweging in België,} organisatorische en ideologische evolutie

De arbeiderssportbeweging had zich in België na de Eerste Wereldoorlog sterk weten te ontwikkelen. Daar waar de beweging vóór 1919 enkel turnbonden verenigde, ontwikkelde de arbeiderssport zich nadien zowel in de breedte als kwantitatief, van 57 bonden met 3000 leden in 1914 naar 240 bonden met 15.000 leden in 1921. Naast het turnen, werd voetbal de belangrijkste sporttak.

Naast de traditionele aandachtspunten zoals samenwerking en verbroedering hechtte de leiding van de arbeiderssportbeweging in België bijzonder belang aan de ontwikkeling van een gezonde lichaamscultuur en aan de nieuwe pedagogische principes. De arbeiderssportbeweging was trouwens structureel verbonden met de socialistische jeugdbeweging en het opvoedkundige aspect werd minstens zo belangrijk als het politieke. Aan jonge arbeiders en arbeidsters werden de basisprincipes van persoonlijke hygiëne bijgebracht, al zeer vroeg was er aandacht voor de medische begeleiding van de sporters, 
de arbeiderssportbeweging schakelde zich in in de anti-alcohol en anti-tabakacties van de socialistische jeugd, verspreidde mee het esperanto-ideaal en de coëducatie van jongens en meisjes. Binnen de traditioneel kathölieke samenleving die België toen nog in grote mate was, botsten dergelijke opvattingen op grote weerstand.

De arbeiderssport en de jongerenbeweging waren ook de ideale voedingsbodem voor de ideologische vernieuwing, die zich vanaf de jaren dertig binnen de socialistische beweging begon te manifesteren. De oude, zuiver klassegerichte ideologie, die ook één van de pijlers was van de arbeiderssportbeweging, werd door een nieuwe generatie van socialisten in vraag gesteld. De ideeën van de Nederlander Koos Vorrinck en van Hendrik De Man, die ingingen tegen het oude klassegerichte denken vonden een gretige aanhang bij de arbeiderssporters. De oude theorieën werden als te deterministisch gezien, de verantwoordelijkheid en de mogelijkheden van het individu werden door hen meer beklemtoond. Hun opvoedingsideaal ambieerde de ontwikkeling van een 'nieuwe mens', die het socialisme 'in zich draagt'.

De economische crisis, de internationale doorbraak van het fascisme en de aanvallen tegen de Spaanse republiek radicaliseerden de arbeidersjeugd- en sportbewegingen, die zowel ideologisch als organisatorisch een vernieuwende dynamiek gingen ontwikkelen.

\section{De Arbeidersolympiade van Antwerpen}

De organisatie van de Derde Arbeidersolympiade in 1937 te Antwerpen kwam voor de Belgische arbeiderssportbeweging dan ook op een moment van hernieuwd enthousiasme. De eco- nomische crisis was voorbij, de arbeidersbeweging had in 1936 de grootste staking van de eeuw succesvol afgerond met onder andere de verovering van het betaald verlof en binnen de socialistische beweging voltrok zich in snel tempo een generatiewissel. De stad Antwerpen was bovendien een brandpunt van internationale anti-fascistische actie. Tienduizenden joodse vluchtelingen zetten zich in voor een actieve boycot van nazi-Duitsland. De Antwerpse socialistische vakbeweging herbergde Duitse syndicalisten die aan de haven anti-nazi-activiteiten ondernamen en was zelf actief in de wapenbevoorrading van de Spaanse Republiek. De burgemeester, Camille Huysmans, was als oud-secretaris van de Socialistische Internationale bovendien zowat de verpersoonlijking van het anti-fascisme.

De Derde Arbeidersolympiade stond dan ook in het teken van de internationale strijd tegen het fascisme en de solidariteit met de Spaanse Republiek. Het feit dat het jaar ervoor de volksolympiade van Barcelona, georganiseerd als protest tegen de olympiade van Berlijn, al na één dag moest afgebroken worden wegens het beginnende oorlogsgeweld, gaf hieraan een extra dimensie. De Spaanse delegatie met 170 atleten was de eregast in Antwerpen. Ze werd aangevoerd door Julius Deutsch, de Oostenrijkse voorzitter van de ISOS, die op dat moment generaal was van de Internationale Brigaden in Spanje.

Naast de Spaanse delegatie waren er ook kleine delegaties van Duitse, Oostenrijkse en joodse arbeiderssporters, maar met een totaal van ongeveer 20.000 deelnemers scoorde Antwerpen wel beduidend lager dan zowel Frankfurt als Wenen. Spectaculair was de aanwezigheid van de sovjetdelegatie met 55 atleten; het was een bevestiging van de structurele samenwerking tussen de ISOS en de IRS sinds 1934. 
De aanwezigheid van de Russische delegatie had evenwel ook onverwachte gevolgen. De Sovjet-Unie had namelijk topsporters gestuurd en hoewel ze met 55 atleten de op één nạ kleinste delegatie had, voerde ze de overwinningstabel aan met 26 eerste plaatsen. De sovjetatleten braken tijdens deze arbeidersolympiade niet minder dan drie wereldrecords én éen Europees record. De zwemmer Boitsjenko ver beterde het wereldrecord op de honderd meter vlinderslag met bijna drie seconden. Dé socialistische media reageerden euforisch en brachten het sensationele nieuws in grote opmaak in de pers en het publiek ging in groten getale naar de competities kijken. Maar anderen kloegen dat de arbeiderssport haar eigen identiteit aan het verliezen was, dat de competitie het gewonnen had op het samenzijn. Voor de Nederlanders was de aanwezigheid van de Russische topatleten zelf reden voor een gedeeltelijke boycot van de olympiade.

Toch was ook de Arbeidersolympiade van Antwerpen in de eerste plaats een massagebeuren, met optochten, rally's, concerten, massaturndemonstraties, een kinderdag, een massaspel en een fakkeltocht. Bijzondere aandacht ging ook naar de voedselvoorziening en de medische verzorging. De organisatoren hadden een beroep gedaan op SERSANO, de 'Service Sanitaire Ouvrier', een autonome arbeidersgezondheidsdienst die al sinds 1932 actief was en afdelingen had in het ganse land. Alle atleten werden aan een medische controle onderworpen, terwijl de medische hulp- en gezondheidsdienst dag en nacht beschikbaar was.

Maar alle inspanningen en enthousiasme ten spijt, kon de Antwerpse Arbeidersolympiade de crisis binnen de internationale arbeiderssportbeweging niet verbergen. De anti-competitieve en niet-prestatiegerichte sportopvattingen gin- gen stilaan tot een vervlogen wereld behoren. De arbeidersklasse zelf was in grote mate in de ban van de prestatiesport, de arbeiderssportbeweging kon hiertegen slechts een beperkt tegengewicht bieden. En het fascisme vormde voor de arbeiderssportorganisaties een existentiële bedreiging. Eén jaar na de olympiade werd de ISOS nagenoeg gebroken door het verlies van de Tsjechische bonden. Van de 2 miljoen leden in 1930, waren er nauwelijks nog enkele tienduizenden over.

De Tweede Wereldoorlog betekende het einde van de ISOS. $\mathrm{Na}$ de oorlog zou het 'Comité Sportif International du Travail', dat nog altijd actief is, de traditie voortzetten, zonder evenwel ooit de uitstraling te bereiken van zijn tussenoorlogse voorganger.

(1) Voordracht van Geert Van Goethem gehouden voor de IALHI-conferentie te Barcelona, 25-27 september 1996. 